occupied mainly in the Food Production Department; but he had a large share, also, in the provision of data for the early work of the first Agricultural Wages Board, set up in 1917. He returned to Oxford in 1920, remaining there until 1924, when he was elected lecturer in agricultural economics in the University College of Wales, Aberystwyth, an appointment which was raised to a professorial chair five years later. Thus he continued until 1946, when he returned once again to Oxford as director of the Agricultural Economics Research Institute, to retire finally in December last.

All through his life, Ashby showed an immense capacity for work. His early experiences as a member of a farm-worker's family at the end of the past century, and his own achievement of an education from village school to university standard in the days when this was not an easy accomplishment, had given him a deep and lasting interest in education and its provision on a wider scale for those capable of profiting by it. At Aberystwyth he created the school of agricultural economics, and when that was established as the foremost place of study of the subject in the United Kingdom, he went on to found a postgraduate school which achieved an international reputation, attracting graduate students from all parts of the world. This interest was further developed during his last years, when the research institute at Oxford became the Mecca of students from the Commonwealth, the United States and other places. Subsidiary to this work was his interest in administration. So early as 1919 he had been a member of the Royal Commission on Agriculture, and three years later he served on a departmental committee on prices of farm produce. Marketing problems became his particular study, especially co-operative organization, and when the co-operative movement in English agriculture suffered its lamentable collapse in 1920, more credit was due to him, probably, than to any one supporter that the Welsh Agricultural Organization Society survived, to extend $i$ ts influence in Welsh rural life in subsequent years.

Other bodies on which Ashby served with distinction were the second Agricultural Wages Board, set up by the first Labour administration in 1924, and the councils of agriculture for England and for Wales. He did much to promote the good of the Young Farmers' Clubs movement, and the efforts of the Women's Institutes to secure better conditions in rural social life.

From this record it will be apparent that Ashby's main preoccupation was the human side of the work that offered, and that his direct contributions to economic research and its literature were subordinated to it. Nevertheless, the influence which he exercised on the development of his subject cannot be over-estimated, and he was an inspiration to all those-and they were many-with whom his life brought him into contact. C. S. ORWIN

\section{Mr. James Fairgrieve}

THE death of James Fairgrieve at the age of eighty-three removes one of the few remaining members of the band of reformers whose work has given us the modern concept of geography, and who have seen in their lifetime its firm establishment throughout the schools as a subject of major cultural value and in all British universities as a discipline of comparable worth-all largely as a result of their own activities. A son of the manse, he was born at
Saltcoats in 1870 and enjoyed the advantages of a peripatetic Scottish education at Saltcoats, Ardrossan and Glasgow before proceeding as an Exhibitioner in both cases to Aberystwyth and to Jesus College, Oxford, where he graduated M.A. His early interests were classical and mathematical, and for periods in his early life he held the posts of mathematics master at Kelso and Campbeltown before appointment as head of the New Southgate High School in London. But he fell under the same spell as Herbertson, with whom he worked at Oxford, Halford Mackinder, under whom he studied at the London School of Economics, B. B. Dickinson of Rugby, and H. J. Fleure, to appreciate in the reform of geography the keystone of a new humanist teaching.

In 1907 Fairgrieve gave up his headship to become geography master and second master at the William Ellis School in North London. There he established what was perhaps the first 'geography room'-a well-equipped room set apart for the teaching of geography and which he regarded as important a necessity as a laboratory for chemistry or for physics. His view in this regard has now become fully accepted and the provision of such a room in schools is standard practice. He was forty-two when he was appointed to the post of lecturer in education with special reference to geography at the old London Day Training College for Teachers, afterwards the Institute of Education of the University of London. There he was destined to wield a remarkable influence for nearly a quarter of a century (1912-35) over successive generations of teacher-trainees taking their teacher's diploma after graduation in the University of London. In those years he seemed to change little. Tall, cadaverous, with a slight stoop, an unruly shock of iron-grey hair and an unkempt walrus moustache, he talked to his classes as if they were not there, yet with a burning enthusiasm which never failed to impress and endear. A martyr to digestive troubles, he subsisted for years on a small, thin, well-done piece of steak with nothing else; in later years he felt the cold increasingly, and seemed rarely to emerge from a great shaggy woollen overcoat which only served to enhance a vivid personality.

Fairgrieve neither under-estimated nor scorned the different ways of achieving reform. He knew that one may preach reform in the teaching of a subject for years without result: put one question in a public examination paper of a new type and teachers will adapt their courses overnight. Give the teacher the text-books with the new view and reform is assured. So he did an immense amount of examining and wrote many text-books. Most of the latter were in conjunction with Ernest Young-a short, rotund, insatiable traveller and bon viveur. Especially through the six books for the primary school and the three books for the secondary which formed the set of Fairgrieve and Young's "Human Geographies" (which have passed through innumerable editions), geography became something quite different in British schools. Critics to-day may say that the pendulum swung too far : in stressing the human aspects the essential physical basis and logical approach tended to be lost; but this was never intended by Fairgrieve himself. He believed firmly in personal observation for himself and the youngest school child alike, and so developed his interest in local and regional surveys and in microclimatology.

The film was hailed as a powerful new instrument in education, and it was natural to find Fairgrieve not only president of the Geographical Association 
(1935), and vice-president of the Royal Meteorological Society (1932-33), but also original member of the Commission on Cultural and Educational Films. His sphere of interest widened when during 1927-35 he held the post of head of the Department of Colonial Education concurrently with his lectureship (readership from 1931) at the Institute of Education. Although he retired under the age limit in 1935 , he never retired from active geographical work. As a result of an unfortunate accident he was temporarily crippled, and if he cursed mildly at the inconvenience of a wheel chair it did not deter him from attendance at the executive meetings of the Geographical Association to the very last, nor did his genius for helpful friendship ever leave him. O si sic omnes!

L. Dudley Stamp

\section{NEWS and VIEWS}

\section{Royal Society: Medal Awards}

THe following awards of medals have been made by the president and the Council of the Royal Society : Copley Medal to Prof. A. J. Kluyver, For.Mem.R.S., for his distinguished contributions of a fundamental character to the science of microbiology; Davy Medal to Sir John Lennard-Jones, K.B.E., F.R.S., for his distinguished work on the applications of quantum mechanics to the theory of valency and to the analysis of the intimate structure of chemical compounds; Hughes Medal to Sir Edward Bullard, F.R.S., for his important contributions to the development, both theoretical and experimental, of the physics of the earth.

\section{Nobel Prize for Chemistry for 1953 : \\ Prof. H. Staudinger}

THE chemistry of macromolecules has become so commonplace and so well defined that it is difficult to realize how hard the pioneers had to work to convince their scientific colleagues that macromolecules existed at all. The award of the Nobel Prize for Chemistry to Prof. Herman Staudinger sets a seal on this achievement. He was one of the pioneers of the subject long before it became of popular appeal. Many of the basic ideas about macromolecules were beginning to be accepted about the mid-thirties, but for many years before this date Staudinger was one of the very few who showed, by the use of the classical methods of organic chemistry, that small molecules form polymers not simply by a physical process of aggregation but by real chemical interaction. He demonstrated that linear molecules could be built up synthetically in this way by a variety of processes and, what is more, maintain their individuality even though they are subject to chemical modification. Again by classical methods he showed how it was possible to build up high-polymer net-works, and that such net-works would only expand to a finite extent if immersed in suitable solvents. One of his best known contributions is the establishment of the relationship between the viscosity of a solution of a high polymer and its molecular weight. The utilization of this relation permitted, by extrapolation, the estimation of molecular weights of high polymers in molecular-weight regions where no other method was at that time available. Although the relationship has been modified as more knowledge became available about these matters, viscosity methods are, without doubt, the most extensively used as a convenient and simple means of obtaining information about molecular weights of very many polymers. Nobel Prizes are often awarded for an outstanding discovery that ultimately has wide ramifications: with Prof. Staudinger it is the reward for a life-time of effort in a field that has only comparatively recently been accepted as a growing and important branch of both physical and biological science.

\section{Engineering at University College, Dundee :}

Prof. J. Dick

Dr. J. Dick, who has been appointed to the chair of engineering and drawing in University College, Dundee (University of St. Andrews), as from April 1, 1954, graduated from the University of Glasgow with first-class honours in electrical and mechanical engineering in 1930. He worked in industry with the Albion Motor Car Co. before joining the late Prof. F. C. Lea at the University of Sheffield as a research assistant. A few years later he became a member of the mechanical engineering lecturing staff at that University, and in 1933 received the degree of Ph.D. Later he was appointed to his present post, the Donald Pollock readership in engineering science in the University of Oxford. Though his interests have been concerned mainly with mechanical engineering, they cover a wide range of subjects. He has been concerned with investigations on stresses in wire drawing, the fatigue of engineering materials, mechanical vibrations and lubrication, and has worked on boundary layers and heat transfer in fluid flow. He has published papers on most of these subjects. Prof. Dick is a member of the Institution of Mechanical Engineers, and has taken an active interest in the affairs of the Institution, having acted as honorary secretary of the Yorkshire Branch for five and a half years during the period 1940-45. In taking up the chair at Dundee, Prof. Dick is returning to his own part of the country, as he is a native of Fife.

\section{Work on Guided Missiles at Woomera}

IN the House of Commons on October 27, in reply to a question regarding his recent visit to Woomera in connexion with the guided rocket programme, and his discussions with the Australian Government, the Minister of Supply, Mr. Duncan Sandys, stated that it had been agreed that the United Kingdom Government should, in future, bear the cost of any further work of this kind which might be done in Australia to its order. The Australian Government has agreed to take over a larger financial responsibility for range equipment ordered by it in the United Kingdom. Apart from basic research, which is not tied to a particular weapon and which goes on continuously, there are threc main phases in the development of guided missiles. The first is the design and construction of prototypes; the second, the carrying out of trials and the introduction of modifications indicated to be necessary; and thirdly, there is the manufacturing phase, in which the aircraft or rocket goes into quantity production. It is in the trials stage, said Mr. Sandys, that the vast and well-equipped Woomera range is of such 